\title{
Factors Associated with Healthy Preventive Behavior among the Elderly in Lamongan, East Java
}

\author{
Nurul Jannah'), Didik Tamtomo², RB Soemanto3) \\ ${ }^{1)}$ Masters Program in Public Health, Universitas Sebelas Maret \\ 2)Faculty of Medicine, Universitas Sebelas Maret \\ 3)Faculty of Social and Political Sciences, Universitas Sebelas Maret
}

\begin{abstract}
Background: Health promotion behaviors in the elderly have potential effects in promoting health and quality of life and reducing the cost of health care services. Changes in the lifestyle of the people affected by cardiovascular diseases have more potential shares in reducing vascular problems than medicinal treatments of hypertension and high cholesterol. By convincing more people to maintain and obtain healthy lifestyles, there will be considerable reduction in emergence and disabilities due to cardiac problems. This study aimed to determine factors associated with health preventive behavior among the elderly in Lamongan, East Java.

Subjects and Method: This was a cross sectional study conducted in Lamongan, East Java, from November to December 2018. A sample of 200 elderly was selected by stratified random sampling. The dependent variable was health behavior. The independent variables were education, attitude, peer support, family support, cadre support, perceived behavioral control, subjective norm, and intention. The data were collected by questionnaire and analyzed by a multiple linear regression.

Results: Health behavior in elderly was influenced by education $(b=0.76 ; 95 \% \mathrm{CI}=0.27$ to 1.24; $\mathrm{p}=0.002)$, intention $(\mathrm{b}=0.08 ; 95 \% \mathrm{CI}=0.01$ to $0.16 ; \mathrm{p}=0.033)$, attitude $(\mathrm{b}=0.20 ; 95 \% \mathrm{CI}=$ 0.07 to $0.33 ; \mathrm{p}=0.002)$, perceived behavioral control $(\mathrm{b}=0.18 ; 95 \% \mathrm{CI}=0.06$ to $0.30 ; \mathrm{p}=0.002)$, family support $(\mathrm{b}=0.19 ; 95 \% \mathrm{CI}=0.08$ to $0.30 ; \mathrm{p}=0.001)$, cadre support $(\mathrm{b}=0.13 ; 95 \% \mathrm{CI}=$ 0.04 to $0.23 ; \mathrm{p}=0.005)$, peer support $(\mathrm{b}=0.07 ; 95 \% \mathrm{CI}=-0.01$ to $0.15 ; \mathrm{p}=0.060)$, and subjective norm $(\mathrm{b}=0.10 ; 95 \% \mathrm{CI}=-0.01$ to $0.22 ; \mathrm{p}=0.064)$.
\end{abstract}

Conclusion: Health behavior in elderly is influenced by education, intention, attitude, perceived behavioral control, family support, cadre support, peer support, and subjective norm.

Keywords: health behavior, elderly, linear regression

\section{Correspondence:}

Nurul Jannah. Masters Program in Public Health, Universitas Sebelas Maret, Jl. Ir. Sutami 36A, Surakarta 57126, Central Java, Indonesia. Email: njannah.31@gmail.com.

Mobile: +6282230300405 .

\section{BACKGROUND}

Indonesia is an old structured country. This aging population structure is one indicator of the success of achieving global and national human development. In Indonesia national development in various fields has improved the quality of health and the socio-economic conditions of the community. From the results of the 2010 population census the population of Indonesia has a life expectancy(UHH) reaches the age of 70 years and is much better than the $\mathrm{UHH}$ number three or four decades before, ie under 60 years (Central Bureau of Statistics, 2015).

Elderly is someone who reaches the age of 60 years and over, this is based on Law Number 13 of 1998 concerning elderly welfare. Elderly health intervention efforts are implemented through the life cycle starting in the womb until adulthood, which in turn will have a major impact on the creation of healthy, productive and 
Journal of Health Promotion and Behavior, 2018, 3(4): 223-229

https://doi.org/10.26911/thejhpb.2018.03.04.01

independent elderly people in the future (Ministry of Health, 2016).

Until 2015 the elderly posyandu that provided promotive and preventive health services spread in 23 provinces in Indonesia with 83,442 elderly posyandu, the highest number of elderly posyandu in East Java Province with a total of 54,522 elderly posyandu and in Lamongan District there were 494 elderly posyandu with 78 achievement targets \% (RI Ministry of Health, 2016).

Based on 2017 East Java health profile data, the number of elderly is 4,640,440 people and those receiving health services are 2,873,233 people. While in Lamongan Regency the number of elderly people is 149,070 people with the number of elderly who get health services 118,941 people (79.79\%) of the total number of elderly people who are there (Lamongan District Health Office, 2017).

\section{SUBJECTS AND METHOD \\ 1. Study Design \\ This study was an observational analytic study with a cross sectional approach. It was conducted in East Java Lamongan Regency in November-December 2018.}

\section{Population and Samples}

The population used in this study is the continuation of the East Lamongan Regency, which is in the range of 25 Posyandu lansia in Lamongan Regency, East Java. The samples consist of 200 research subjects. The samples were selected using stratified ramdom sampling technique.

\section{Research Variables}

The independent variables are education, attitudes, peer support, family support, cadre support, perceptions of behavioral control, subjective norms, and intentions. The dependent variable is old age healthy behavior.

\section{Operational Definition of Variables} Education is a learning process that has been taken until graduating through formal education.

Attitude is the response of the elderly to the use of posyandu in the effort of healthy behavior by participating in the posyandu for the elderly. Attitudes are measured on a continuous scale of data.

Peer support is the support of people with the same age and maturity who can influence elderly people to behave in healthy old age by attending the posyandu for the elderly. Peer support is measured on a continuous data scale.

Family support is family support in the form of encouragement, empathy, motivation, and assistance to the elderly to continue healthy behavior. Family support is measured on a continuous data scale.

Cadre support is the motivation of posyandu cadres to the elderly to behave in healthy behavior by participating in the elderly posyandu program. Cadre support is measured on a continuous data scale.

Behavioral control perceptions are a person's perception of the assessment of difficult or easy to behave in old age by attending an elderly posyandu. Behavioral control perceptions are measured in continuous data scales.

Subjective norms are a person's perception of social demands to do or not do old age healthy behavior by attending the posyandu for the elderly. Subjective norms are measured in continuous data scales.

Intention is the desire or inclination of a person to behave in healthy old age. Healthy behavior is a person's activities related to maintaining and improving health which includes preventing and protecting from illness, and seeking treatment. The intention is measured in a continuous data scale. 


\section{Data Analysis}

Sample characteristics were describe by univariate analysis. Bivariate analysis used Chi square. Multivariate analysis used a multiple linear regression.

\section{Etika Penelitian}

The research ethical clearance was obtained from the Research Ethics Committee Faculty of Medicine, Universitas Sebelas Maret, Surakarta, Central Java, Indonesia, with number: 310/UN27.6/KEPK/2018. Research ethics included informed consent, anonymity, confidentiality, and ethical clearance.

\section{$\frac{\text { RESULTS }}{\text { Sample Characteristics }}$ \\ Table 1 shows that elderly people with unhealthy behavior were 62 (31\%), while the elderly who had positive healthy Table 1. Sample Characteristics}

\begin{tabular}{lcc}
\multicolumn{1}{c}{ Sample Characteristics } & Total (n) & Percent (\%) \\
\hline Elderly Healthy Behavior & 62 & 31 \\
Negative & 138 & 69 \\
Positive & & \\
Education & 167 & 83.5 \\
Low & 33 & 16.5 \\
High & & 52 \\
Behavior & 104 & 48 \\
Negative & 96 & 55 \\
Positive & & 45 \\
Peer Support & 110 & \\
Weak & 90 & 50.5 \\
Strong & & 49.5 \\
Family Support & 101 & 50 \\
Weak & 99 & 50 \\
Strong & & \\
Cadre Support & 100 & 49 \\
Weak & 100 & 51 \\
Strong & & 62 \\
Perceived behavior control & 98 & 38 \\
Negative & 102 & 47 \\
Positive & & 53 \\
Nubjective Norms & 124 & \\
Positive & 76 & \\
Intention & & \\
Low & 106 & \\
High & & \\
\hline
\end{tabular}

behavior were 138 (69\%). Elderly with low education were 167 (83.5\%), while those who had high education were 33 (16.5\%). As many as 104 elderly (52\%) had negative attitude. As many as 110 elderly (55\%) received weak peer support. As many as 101 elderly (50.5\%) received weak family support.

\section{Bivariate analysis}

Table 2 showed that education $(r=0.31$; $\mathrm{p}<0.001)$, attitude $(\mathrm{r}=0.43 ; \mathrm{p}<0.001)$, peer support $(\mathrm{r}=0.32 ; \mathrm{p}<0.001)$, family support $(\mathrm{r}=0.49 ; \mathrm{p}<0.001)$, cadre support $(\mathrm{r}=0.41$; $\mathrm{p}<0.001)$, perceived behavior control, $(\mathrm{r}=$ $0.39 ; \mathrm{p}<0.001)$, subjective norm and $(\mathrm{r}=$ $0.38 ; \mathrm{p}<0.001)$, and intention $(\mathrm{r}=0.39$; $\mathrm{p}<0.001)$ were associated with healthy behavior among elderly 
Journal of Health Promotion and Behavior, 2018, 3(4): 223-229

https://doi.org/10.26911/thejhpb.2018.03.04.01

Table 2. The Result of Pearson Correlations Analysis

\begin{tabular}{lccc}
\hline \multirow{2}{*}{ Independent Variables } & \multicolumn{3}{c}{ Determinant of healthy behavior among elderly } \\
\cline { 2 - 4 } \multicolumn{1}{c}{$\mathbf{N}$} & $\mathbf{r}$ & $\mathbf{p}$ \\
\hline Education & 200 & 0.31 & $<0.001$ \\
Attitude & 200 & 0.43 & $<0.001$ \\
Peer Support & 200 & 0.32 & $<0.001$ \\
Family Support & 200 & 0.49 & $<0.001$ \\
Cadre Support & 200 & 0.41 & $<0.001$ \\
Perceived Behavioral Control & 200 & 0.39 & $<0.001$ \\
Subjective Norm & 200 & 0.38 & $<0.001$ \\
Intention & 200 & 0.39 & $<0.001$ \\
\hline
\end{tabular}

\section{Multivariate Analysis}

Table 3 showed that education $(b=0.76$; 95\% $\mathrm{CI}=0.27$ to $1.24 ; \mathrm{p}=0.002$ ), attitude $(b=0.20 ; 95 \% \mathrm{CI}=0.07$ to $0.33 ; \mathrm{p}=0.002)$, family support $(b=0.19 ; 95 \% \mathrm{CI}=0.08$ to $0.30 ; \mathrm{p}=0.001)$, cadre support $(\mathrm{b}=0.13$; $95 \% \mathrm{CI}=0.04$ to $0.23 ; \mathrm{p}=0.005$ ), perceived behavioral control $(\mathrm{b}=0.18 ; 95 \% \mathrm{CI}=0.06$ to $0.30 ; \mathrm{p}=0.002)$, intention $(\mathrm{b}=0.08$;

Table 3. The Result Linear Regression Analysis

\begin{tabular}{|c|c|c|c|c|}
\hline \multirow{2}{*}{ Independent Variables } & \multirow{2}{*}{ b } & \multicolumn{2}{|c|}{ CI (95\%) } & \multirow[b]{2}{*}{$\mathbf{p}$} \\
\hline & & Lower Limit & Upper Limit & \\
\hline Education & 0.76 & 0.27 & 1.24 & 0.002 \\
\hline Attitude & 0.20 & 0.07 & 0.33 & 0.002 \\
\hline Peer Support & 0.07 & -0.00 & 0.15 & 0.060 \\
\hline Family Support & 0.19 & 0.08 & 0.30 & 0.001 \\
\hline Cadre Support & 0.13 & 0.04 & 0.23 & 0.005 \\
\hline Perceived Behavioral Control & 0.18 & 0.06 & 0.30 & 0.002 \\
\hline Subjective Norm & 0.10 & -0.00 & 0.22 & 0.064 \\
\hline Intention & 0.08 & 0.00 & 0.16 & 0.033 \\
\hline \multicolumn{5}{|l|}{ n observation $=200$} \\
\hline \multicolumn{5}{|l|}{ Adj R-Squared $=0.47$} \\
\hline $\mathrm{p}<0.001$ & & & & \\
\hline
\end{tabular}

\section{DISCUSSIONS}

1. The relationship between education and healthy behavior among elderly

The result of this study showed that there was a relationship between education and healthy behavior among elderly. The result of this study was in line with a study by $\mathrm{He}$ et al., (2016) which stated that there was a relationship between education and healthy behavior among elderly in rural China. The level of education of the elderly has signi-
95\% $\mathrm{CI}=0.00$ to $0.16 ; \mathrm{p}=0.033$ ) were associated with healthy behavior of elderly.

Peer support $(b=0.07 ; 95 \% \mathrm{CI}=-0.01$ to $0.15 ; \mathrm{p}=0.060)$ and subjective norm $(\mathrm{b}=$ $0.10 ; 95 \% \mathrm{CI}=-0.01$ to $0.22 ; \mathrm{p}=0.064)$, were positively associated with healthy behavior but they were statistically nonsignificant. ficant differences in their health knowledge and behavior.

The result of this study was in line with Aldriana \& Daulay (2016) who stated that there was a significant relationship between education and elderly visits to elderly health center.

\section{The relationship between attitude and healthy behavior among elderly}

The result of this study showed that there was a relationship between attitude and 
healthy behavior among elderly which was statistically significant. The result of this study was in line with a study by Deng et al., (2014) which stated that there was an effect of attitude on healthy behavior among elderly.

The result of this study was in line with a study by Alhidayati (2014) which stated that attitude has a relationship with healthy behavior of elderly by visiting elderly health center. The attitude was related to with the behavior of visiting elderly health centers to get health services in an effort to have healthy behavior.

\section{The relationship between peer sup- port and healthy behavior among elderly}

The result of this study showed that there was no relationship between peer support and healthy behavior among elderly which was statistically insignificant. The result of this study was in line with Hempler et al., (2016) which stated that there was no relationship between peer support and healthy behavior among elderly. The lack of social norm and social networkcan lead to stress and poor healthy behavior.

The result of this study was in line with a study done by Lestari et al., (2011) which stated that there was no effect of peer support on elderly visits to elderly health centers.

\section{The relationship between family support and healthy behavior among elderly}

The result of this study showed that there was a relationship between family support and healthy behavior among elderly which was statistically significant. The result of this study was in line with a study by Waterworth et al., (2015) which stated that family support gave a positive impact on health behavior of elderly.

The result of this study was in line with a study by Huidobro \& Mendenhall
(2015) which stated that family context was the place to learn health behavior. The family was the main support system for the elderly in maintaining their health. Elderly who got support from their family members would have high quality of life.

\section{The relationship between cadre support and healthy behavior among elderly}

The result of this study showed that there was a relationship between cadre support and healthy behavior among elderly which was statistically significant. The result of this study was in line with a study done by Setyoadi et al. (2013) which stated that there was a significant relationship between the role of cadres and the quality of life of the elderly, because the role of a good cadre influenced the level of quality of life of the elderly because cadres always provided positive support and education to the elderly to conduct routine checks.

The result of this study was in line with a study by Puspitasari et al., (2017) which stated that elderly who use elderly gymnastics were more commonly found in the elderly who got strong support from cadres $(57.6 \%)$ and p-value was 0.012 , so that there was a relationship between environmental support and the use of elderly gymnastics, elderly gymnastics was an effort to improve elderly health.

\section{The relationship between percei- ved behavioral control and healthy behavior among elderly}

The result of this study showed that there was a relationship between perceived behavioral control and healthy behavior among elderly which was statistically significant. The result of this study was in line with a study done by Bartwal et al., (2016) which stated that perceived behavioral control has a significant relationship with the treatment for elderly. 
The result of this study was in line with a study by Watanabe et al., (2015) which stated that perceived behavioral control has a significant relationship. The concept of TPB in clinical practice can help diabetics to change their food intake.

\section{The relationship between subjec- tive norm and healthy behavior among elderly}

The result of this study showed that there was no relationship between subjective norm and healthy behavior among elderly which was statistically insignificant. The result of this study was in line with a study done by Deng et al., (2014) which stated that subjective norms did not show a significant effect on the use of cellular health services in China.

The result of this study was in line with a study by Alberta et al.,(2014) which stated thatsubjective norms did not show an effect on doing a low salt diet in elderly people with hypertension.

\section{The relationship between inten- tion and healthy behavior among elderly}

The result of this study showed that there was a relationship between intention and healthy behavior among elderly which was statistically significant. The result of this study was in line with a study by Quaosar \& Hoque (2018) which stated thatthere was an effect of intention on the use of m-health services in China, m-health as an important part of e-health has recently became one of the most influential initiatives in the health sector in the world.

Gerayllo and Karimiankakolaki (2015) stated that there was a significant relationship between intention and selfcare behavior in the Yazd area.

\section{REFERENCES}

Alberta LT, Proboningsih J, Almahmudah M (2014). Peningkatan perilaku diet rendah garam berbasis theory of planned behavior (TPB) pada lansia penderita hypertensi. Jurnal Ners, 9(2).

Aldriana N, Daulay R (2016). Faktor - faktor yang berhubungan dengan rendahnya kunjungan lansia. Jurnal Maternity and Neonatal, 2(2).

Alhidayati 2014. Faktor-faktor yang berhubungan dengan perilaku kunjungan lansia ke posyandu lansia di Puskesmas Kampar Kabupaten Kampar Tahun 2013. Jurnal Kesehatan Komunitas, 2(5).

Badan Pusat Statistik, 2015. Statistik penduduk lanjut usia 2014. Jakarta: Badan Pusat Statistik.

Bartwal J, Rawat CMS, Awasthi S (2016). A community based cross-sectional study on self-perception of health status and health seeking behaviour among elderly population in Haldwani block, Uttarakhand. International Journal of Medical Science and Public Health, Volume 5 .

Deng Z, Mo X, Liu S (2014). Comparison of the middlle-aged and older user's adoption of mobile health services in China. Internasional Journal of Medical Informatics, 83(3).

Dinas Kesehatan Kabupaten Lamongan, 2017. Profil kesehatan Kabupaten Lamongan Tahun 2016. Lamongan.

Gerayllo S, Karimiankakolaki Z (2015). Self-care activities and behavioral intention toward self-care in older adults suffering from knee osteoarthritis in Yazd, Iran. Elderly Health Journal.

Hempler NF, Joensen LE, Willaing I (2016). Relationship between social network, social support and health behaviour in people with type 1 and type 2 diabetes: cross sectional studies. BMC Public Health. 
He Z, et al. (2016). Factors influencing health knowledge and behaviors. Internasional Journal of Environmental Reseach and Public Health.

Huidobro DG, Mendenhall T (2015). Family oriented care: opportunities for health promotion and disease prevention. Journal of Family Medicine and Disease Prevention.

Kementerian Kesehatan RI, 2016. Situasi Lanjut Usia (Lansia) di Indonesia, Jakarta: Pusdatin Dan Kementerian Kesehatan RI.

Lestari P, Hadisaputro S, Pranarka K (2011). Beberapa faktor yang berperan terhadap keaktifan kunjungan lansia ke posyandu studi kasus di Desa Tamantirto Kecamatan Kasihan Kabupaten Bantul Propinsi DIY. Media Medika Indonesia, 45(2).

Puspitasari N, Widjanarko B, Suroto (2017). Faktor-faktor Yang berhubungan dengan pemanfaatan senam lansia di posyandu Kelurahan Sendangmulyo Kota Semarang. Jurnal Kesehatan Masyarakat (e-Journal), 5(5).

Quaosar GA, Hoque MR (2018). Investigating factors affecting elderly's intention to use m-health services: an empirical study. Telemedicine and ehealth.

Setyoadi A, Abidin AY (2013). Hubungan peran kader kesehatan dengan tingkat kualitas hidup lanjut usia. Jurnal Ilmu Keperawatan, 1(2)

Watanabe T, Berry TR, Willows ND, Bell $\mathrm{RC}$ (2015). Assesing intentions to eat low-glycemic index foods by adults with diabetes using a new questionnaire based on the theory of planned behavior. Canadian Journal of Diabetes.

Waterworth P, et al. (2015). Factors influencing the health behaviour of indigenous australians: perspectives from support people. Journal Pone. 